\title{
The Relationship between Family's Assessment Support and MDR TB Patient's Adherence on Treatment in RSUD Dr. Soetomo Surabaya
}

\author{
Safira Nur Ainiyah ${ }^{1}$, Soedarsono ${ }^{2}$, Pirlina Umiastuti $^{3}$
}

\begin{abstract}
${ }^{1}$ Faculty of Medicine, Universitas Airlangga, Surabaya, Indonesia.
2Department of Pulmonology and Respiratory Medicine, Faculty of Medicine, Universitas Airlangga - Dr. Soetomo General Hospital, Surabaya, Indonesia.

${ }^{3}$ Department of Public Health and Preventive Medicine, Faculty of Medicine, Universitas Airlangga, Surabaya, Indonesia.
\end{abstract}

A B S T R A C T

Introduction: Multi Drug-Resistant Tuberculosis (MDR TB) is caused by Mycobacterium tuberculosis and has been resistant to isoniazid and rifampicin. Its treatment needs long time and causes some side effects which can make the patients non-adherent so that family support is needed. This study aims to know the relationship between family's assessment support and MDR TB patient's adherence on treatment in RSUD Dr. Soetomo Surabaya.

Methods: This was an analytic observational cross-sectional study, to know the frequency distribution of family's assessment support, MDR TB patient's adherence, and the relationship between them in 24 MDR TB patients, recruited from MDR TB Clinic, RSUD Dr. Soetomo, Surabaya, from October 2017 to June 2018 and their family. The analysis was descriptive statistic and inferential statistic using Fisher Exact Test.

Results: The results of this study showed that $83.3 \%$ of MDR TB patients' family give high assessment support and $58.3 \%$ of MDR TB patients in RSUD Dr. Soetomo from October 2017 to June 2018 have high adherence on treatment. There is significant $(p=0.020)$, moderate $(c=0.468)$, and direct relationship between family's assessment support and MDR TB patient's adherence on treatment in RSUD Dr. Soetomo Surabaya.

Conclusion: To improve MDR TB patient's adherence on treatment, family must give high assessment support.

*Correspondence: ssoedarsono@gmail.com

JUXTA: Jurnal IImiah Mahasiswa Kedokteran Universitas Airlangga

p-ISSN: 1907-3623; e-ISSN: 2684-9453

DOI: $10.20473 / j u x t a . V 10122019.75-77$

Open access under Creative Commons Attribution-ShareAlike 4.0 International License

(CC-BY-SA)

\section{ARTICLE INFO}

Article history:

Received 06 August 2019

Received in revised form 16 August 2019

Accepted 22 August 2019

\section{Keywords:}

Family's Assessment Support, MDR TB Patient,

Adherence. 


\section{Introduction}

Multi Drug-Resistant Tuberculosis (MDR TB) is caused by Mycobacterium tuberculosis and has been resistant to isoniazid and rifampicin which are the most effective firstline anti tuberculosis drugs. ${ }^{1}$ This drug resistance began to be reported in the end of 1980 and early $1990 .^{2}$ There are 7.4 MDR/RR TB cases/100.000 population around the world in 2017 which its $82 \%$ are MDR TB. Approximately $3.5 \%$ of those cases are new cases and $18 \%$ are previously treated cases. ${ }^{3}$ Based on global tuberculosis report 2018 by $\mathrm{WHO}$, there are 8.8 cases $/ 100.000$ population in Indonesia in 2017 which makes Indonesia included in 30 MDR TB burden countries. ${ }^{3}$

MDR TB is caused by inappropriate use of antibiotics. The resistance is caused by spontaneous chromosal mutation which is gradual by given antimicrobes. ${ }^{4}$ The resistance increases in TB patients which have previous treatment. ${ }^{5}$ MDR TB and TB's transmissions are by droplet nuclei in the air after the patient spoke, sneezed, and coughed. They cannot be spread by sharing food or drinks, handshaking, and sharing toilet. ${ }^{6}$

MDR TB treatment is held in 2 phase in 18-24 months. Initial phase uses injection antituberculosis drug for 6 months and 4 months after negative culture. Advance phase uses non injection antituberculosis drugs. ${ }^{7}$ This long treatment causes MDR TB patients and family feel bored and lazy to get treatment and tend to seek other medical treatments, alternative or traditional, which causes irregular treatment. ${ }^{8}$ Beside that, there are some drugs in the regimen that cause some side effects such as Fluoroquinolones and Ethionamide which cause nausea, vomiting, headache, and tremor. Aminoglycosides can cause ototoxicity, neurotoxicity, and nephrotoxicity. ${ }^{9}$ Kanamycin injection in initial phase can cause renal function disorder, severe electrolytes imbalance, and anaphylactic shock. ${ }^{10}$ MDR TB patients do not want to get their medication because of those side effects. They say that they feel better if they do not drink it which can lead to be non adherence on treatment. To solve this problem, the family has an important role to be the support system when the family member is sick because they are always ready to give help and to care so that the patient does not feel alone in fighting the disease. ${ }^{11}$

According to Sarafino, the family social support can be divided into 4 kinds, which are informational, assessment, emotional, and instrumental supports. Informational support is about giving information and advice to the patient about the disease and treatment. ${ }^{12}$ Assessment support or award support is aimed to give positive award and guidance in solving the problem. ${ }^{13}$ Permatasari says that this support is about giving spirit and support so that the patient will not give up on treatment and urge to recover. Family can remind the patient to get medication regularly so that it can support the success of the treatment. ${ }^{8}$ Emotional support is about asking for confidence and giving care. Giving care is important to motivate fighting the disease and give positive mindset. ${ }^{14}$ Instrumental support is about fulfilling the patient's needs and desires and also finance for treatment. ${ }^{12}$ If the family gives high support, it will support the success of treatment. ${ }^{15}$

This study aims to know the relationship between family's assessment support and MDR TB patient's adherence on treatment in RSUD Dr. Soetomo Surabaya.

\section{Methods}

This research is analytic observational study with cross sectional research design. Sampling technique uses quota sampling by time and got 24 MDR TB patients in MDR TB Clinic RSUD Dr. Soetomo Surabaya from October 2017 to June 2018 and their family. The strength of this sample size has not been measured due to the use of quota sampling by time. The data was collected from interview with both patients and their family. The variables are family's assessment support which is measured using questionnaire and MDR TB patient's adherence which is measured using Morinsky Medication Adherence Scale (MMAS). ${ }^{16,17}$ This questionnaire has been translated into Indonesian language and validated. ${ }^{18,} 19$ The results were analyzed using descriptive statistic for frequency distribution of variables and inferential statistic using Fisher Exact Test to know the relationship between family's assessment support and MDR TB patient's adherence on treatment in RSUD Dr. Soetomo Surabaya. This research has been approved by Health Research Ethics Committee RSUD Dr. Soetomo Surabaya.

Table 1. Characteristic of Sample.

\begin{tabular}{ll}
\hline \multicolumn{1}{c}{ Inclusion } & \multicolumn{1}{c}{ Exclusion } \\
\hline New patient who recieves & Patient lives alone \\
MDR TB Drugs in MDR TB & (without family) \\
Clinic RSUD Dr. Soetomo &
\end{tabular}

Surabaya from October

2017 to June 2018

Patient or family rejected to be respondent

Drop out patient or
passed away

Patient cannot be contacted or fictitious address

Patient is domiciled out of Surabaya

\section{Results}

\section{Frequency Distribution of Family's Assessment Support}

There are 20 families (83.3\%) who give assessment support to MDR TB patients in RSUD Dr. Soetomo Surabaya (Figure 1). 


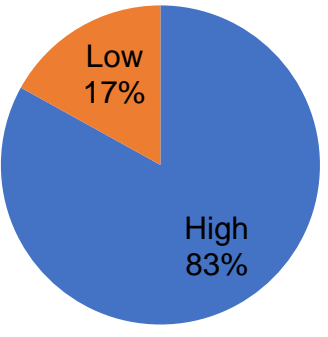

Figure 1. Frequency Distribution of Family's Assessment Support.

\section{Frequency Distribution of MDR TB Patient's Adherence on Treatment in RSUD Dr. Soetomo Surabaya}

MDR TB patient's adherence on treatment in MDR TB Clinic RSUD Dr. Soetomo Surabaya is divided into 2 categories based on score from the interview using MMAS. There are 8 questions which are 7 yes/no questions and a question using likert scale. The score is about 0 to 8 . MDR TB patient has high adherence if the score is about 6 to 8 and low adherence if the score is less than $6 .{ }^{17}$

Table 2. Frequency Distribution of MDR TB Patient's Adherence on Treatment in RSUD Dr. Soetomo Surabaya.

\begin{tabular}{cccc}
$\begin{array}{c}\text { MDR TB } \\
\text { Patient's } \\
\text { Adherence }\end{array}$ & $\begin{array}{c}\text { MMAS } \\
\text { Score }\end{array}$ & Frequency & $\begin{array}{c}\text { Pecentage } \\
(\%)\end{array}$ \\
\hline Low & $<6$ & 10 & 41.7 \\
High & $6-8$ & 14 & 58.3 \\
Total & & 24 & 100 \\
\hline
\end{tabular}

Based on table 2, MDR TB patients in MDR TB Clinic RSUD Dr. Soetomo Surabaya, from October 2017 to June 2018 , have high adherence on treatment which is $58.3 \%$.

\section{Relationship between Family's Assessment Support and MDR TB Patient's Adherence on Treatment in RSUD Dr. Soetomo Surabaya}

Based on table 3, $p$ value is $0.020(\alpha=0.05)$ which indicates that there is significant relationship between family's assessment support and MDR TB patient's adherence on treatment in RSUD Dr. Soetomo Surabaya. The contingency coefficient is 0.468 which indicates the relationsip strength is moderate. It is direct relationship which means that the higher family's assessment role, the higher MDR TB patient's adherence on treatment.
Table 3. Relationship between Family's Assessment Support and MDR TB Patient's Adherence on Treatment in RSUD Dr. Soetomo Surabaya.

\begin{tabular}{lccclll}
\hline Family's & \multicolumn{2}{c}{ Adherence } & Total & $p$ & $\mathrm{C}$ \\
\cline { 2 - 3 } $\begin{array}{c}\text { Assessment } \\
\quad \text { Support }\end{array}$ & + & - & & & \\
\hline High & 14 & 6 & & 20 & 0.020 & 0.468 \\
Low & 0 & 4 & 12 & & \\
Total & 14 & 10 & 24 & & \\
\hline
\end{tabular}

\section{Discussion}

Assessment support or award support is aimed to build patient's self-respect. ${ }^{12}$ This support is about giving spirit, support, and the urge to recover. Self respect is needed because of some discriminations. ${ }^{20}$ Based on table 2, there is significant, moderate, and direct relationship between family's assessment support and MDR TB patient's adherence on treatment in RSUD Dr. Soetomo Surabaya. This result is the same as previous study by Sarafino in Utami et al. which stated that patient who got positive assessment/award support would have more adherence on treatment. ${ }^{12}$ This result is different with previous research by Widyasrini et al. which stated that there wa no relationship between assessment support and the success of MDR TB patient's treatment. ${ }^{13}$

Based on interview with MDR TB patient's family, all family give support and ask not to give up. Those supports are given by fulfilling patient's daily needs and desires, giving spirit, and always asking to get medication. The family asks not to give up by asking directly and giving example of the patient who gets medication regularly and the cured patient. Beside that, they always give motivation so that the patient does not give up. Many family believe that the patient can be cured so that they ask the patient to get medication regularly, give spirit, and forbid them not to have heavy physical activity.

\section{Conclusion}

There is significant, moderate, and direct relationship between family's assessment support and MDR TB patient's adherence on treatment in RSUD Dr. Soetomo Surabaya. The family must give assessment or award support to MDR TB patients so that they will have selfrespect and not give up and leads in improving their adherence on treatment.

\section{CONFLICT OF INTEREST}

The author stated there is no conflict of interest in this study. 


\section{REFERENCES}

1. Danusantoso H. Buku Saku IImu Penyakit Paru. 2nd ed. Jakarta: Penerbit Buku Kedokteran ECG, 2011.

2. Indonesia KKR. Tuberkulosis Temukan Obati Sampai Sembuh. Jakarta: Pusat Data dan Informasi Kementerian Kesehatan Republik Indonesia, 2015.

3. Organization WH. Global Tuberculosis Report 2018. Geneva: World Health Organization, 2018.

4. Caminero J. Guidelines for Clinical and Operational Management of Drug-Resistant Tuberculosis. Paris: International Union Against Tuberculosis and Lung Disease, 2013.

5. Yuni IDAMM. Relationship Between TB Treatment Phase and Knowledge of MDR TB with TB Patient's Compliance. 2017. 2017; 4: 12.

6. Prevention CfDCa. TB Elimination: Multidrug-Resistant Tuberculosis (MDR TB): (2012).

7. Organization WH. Treatment of Tuberculosis: Guidelines. 4th ed. Geneva: World Health Organization, 2010.

8. Manalu HSP. FAKTOR-FAKTOR YANG MEMPENGARUHI KEJADIAN TB PARU DAN UPAYA PENANGGULANGANNYA. 2012.

9. Arbex MA, Varella Mde C, Siqueira HR and Mello FA. Antituberculosis drugs: drug interactions, adverse effects, and use in special situations. Part 2: second line drugs. Jornal brasileiro de pneumologia : publicacao oficial da Sociedade Brasileira de Pneumologia e Tisilogia. 2010; 36: 641-56.

10. Indonesia KKR. Petunjuk Teknis Manajemen Terpadu Pengendalian Tuberkulosis Resistan Obat. Jakarta: Kementerian Kesehatan Republik Indonesia, 2013.

11. Irnawati NM, Siagian IE and Ottay RI. Pengaruh Dukungan Keluarga terhadap Kepatuhan Minum Obat pada Penderita Tuberkulosis di Puskesmas Motoboi Kecil Kota Kotamobagu. Jurnal Kedokteran Komunitas dan Tropik. 2016; 4: 59-64.

12. Utami RS and Raudatussalamah R. Hubungan Dukungan Sosial Keluarga dengan Kepatuhan Berobat Penderita Hipertensi di Puskesmas Tualang. 2017. 2017; $12: 8$.

13. Widyasrini ER, Probandari $A N$ and Reviono. Factors Affecting the Success of Multi Drug Resistance (MDRTB) Tuberculosis Treatment in Residential Surakarta. Journal of Epidemiology and Public Health. 2017; 2: 45-57.

14. Muna $L$ and Soleha U. Motivasi dan Dukungan Sosial Keluarga Mempengaruhi Kepatuhan Berobat pada Pasien TB Paru di Poli Paru BP4 Pamekasan. Jurnal Ilmiah Kesehatan. 2014; 7: 172-9.

15. Kaulagekar-Nagarkar A, Dhake $D$ and Jha $P$. Perspective of tuberculosis patients on family support and care in rural Maharashtra. The Indian journal of tuberculosis. 2012; 59: 224-30.

16. Morisky DE, Ang A, Krousel-Wood M and Ward HJ. Predictive validity of a medication adherence measure in an outpatient setting. Journal of clinical hypertension (Greenwich, Conn). 2008; 10: 348-54.

17. Xu M, Markstrom U, Lyu J and Xu L. Detection of Low Adherence in Rural Tuberculosis Patients in China: Application of Morisky Medication Adherence Scale. International journal of environmental research and public health. 2017; 14.

18. Karuniawati H, Ikawati Z and Gofir A. Pencegahan Sekunder untuk Menurunkan Kejadian Stroke Berulang pada Stroke Iskemik. Jurnal Manajemen dan Pelayanan Farmasi. 2015; 14: 14-21.
19. Saepudin, Padmasari S, Hidayanti P and Ningsih ES. Kepatuhan Penggunaan Obat pada Pasien Hipertensi di Puskesmas. Jurnal Farmasi Indonesia. 2013; 6: 246-53.

20. Chen B, Peng $Y$, Zhou L, et al. Social support received by multidrug-resistant tuberculosis patients and related factors: a cross-sectional study in Zhejiang Province, People's Republic of China. Patient preference and adherence. 2016; 10: 1063-70. 